\title{
Perinatal outcomes in women over 40 years of age compared to those of other gestations
}

\author{
Resultados perinatais em gestantes acima de 40 anos comparados \\ aos das demais gestações
}

\author{
Evandro Eduardo Canhaço ${ }^{1}$, Angela Mendes Bergamo ${ }^{1}$, Umberto Gazi Lippi², \\ Reginaldo Guedes Coelho Lopes ${ }^{1}$
}

\begin{abstract}
Objective: To clarify if older pregnant women were more likely to have adverse perinatal outcomes when compared to women at an ideal age to have a child. Methods: The groups were divided according to age groups: under 20 years, $\geq 20$ to $<40$ years, and $\geq 40$ years. Results: During the period from January $1^{\text {st }}, 2008$, to December $31^{\text {st }}$, 2008 , there were 76 births from patients younger than 20 years and 91 births from patients aged 40 years or over. To form a third group with intermediate age, the data of 92 patients aged 20 to 40 years were obtained, totaling 259 patients. Patients aged 40 or older had a statistically greater number of cesarean sections and less use of forceps or normal deliveries $(p<0.001)$. The use of spinal anesthesia was statistically higher among those aged 40 years or more $(p<0.001)$. The frequency of male newborns was statistically higher in older patients, a group with statistically fewer first pregnancies $(p<0.001)$. The frequency of premature newborns was statistically higher in patients aged 40 years or more $(p=0.004)$. Conclusion: It is crucial to give priority to aged women, so that prenatal care will be appropriate, minimizing maternal complications and improving perinatal outcomes in this unique group.
\end{abstract}

Keywords: Pregnancy; Perinatal care; Maternal age; Age effect; Infant, premature; Cesarean section

\section{RESUMO}

Objetivo: Esclarecer se as gestantes em idade avançada estiveram mais propensas a terem resultados perinatais adversos quando comparadas àquelas em idade reprodutiva ideal. Métodos: 0s grupos foram divididos segundo grupos etários: idade menor que 20 anos; idade maior ou igual a 20 anos e menor que 40 anos; e idade maior ou igual a 40 anos. Resultados: No período compreendido entre $1^{0}$ de janeiro de 2008 a 31 de dezembro de 2008, ocorreram 76 partos de pacientes com idade menor que 20 anos e 91 partos de pacientes com idade maior ou igual a 40 anos. Para a formação de um terceiro grupo de faixa etária intermediária, foram coletados os dados de 92 pacientes com idade maior ou igual a 20 anos e menor que 40 anos, totalizando 259 pacientes. As pacientes com 40 anos ou mais apresentaram estatisticamente maior quantidade de partos cesárea e menos parto a fórcipe ou normais $(p<0,001)$. A aplicação de raquianestesia foi estatisticamente maior nas gestantes com 40 anos ou mais $(p<0,001)$. A frequência de recém-nascido do sexo masculino foi estatisticamente maior nas pacientes mais velhas, que também eram estatisticamente menos primigestas $(p<0,001)$. A frequência de recém-nascido pré-termo foi estatisticamente maior em pacientes com 40 anos ou mais $(p=0,004)$. Conclusão: A priorização no atendimento das gestantes em idade avançada é imprescindível para que o pré-natal seja realizado com segurança, minimizando as complicações maternas e melhorando os resultados perinatais deste grupo tão particular.

Descritores: Gravidez; Assistência perinatal; Idade materna; Efeito idade; Prematuro; Cesárea

\section{INTRODUCTION}

Advanced maternal age causes concern from the obstetric point of view. The extremes of reproductive

\footnotetext{
Hospital do Servidor Público Estadual "Francisco Morato de Oliveira", São Paulo, SP, Brazil.

2 Faculdade de Ciências Médicas, Universidade Metropolitana de Santos, Santos, SP, Brazil.

Corresponding author: Evandro Eduardo Canhaço - Instituto de Assistência Médica ao Servidor Público Estadual de São Paulo, IAMSPE - Rua Pedro de Toledo, 1.800 - Vila Clementino -Zip code: $04039-901$ São Paulo, SP, Brazil - Phone: (55 11) 4573-8085 - E-mail: evandrocanhaco@gmail.com

Received on: June 18, 2014 - Accepted on: Jan 6, 2015

Conflict of interest: none.
}

DOI: 10.1590/\$1679-45082015A03204 
life are linked to a greater frequency of perinatal complications. ${ }^{(1)}$ The ideal age for procreation has been considered by the literature between 20 and 29 years, since during this phase the best maternal and perinatal results are seen. It is also during this period that the greatest number of gestations occur in populations with no birth control. ${ }^{(2)}$

Hence, there is greater maternal and perinatal risks in those women who get pregnant late in their lives. For some authors, regardless of parity, complications are higher. ${ }^{(3,4)}$ Lately, the number of primigravidas over 30 years of age has doubled and has been an $80 \%$ increase in cases of gestations in those aged over 40 years. In the year 2000, approximately $10 \%$ of all births occurred in women 35 years of age or over. ${ }^{(5)}$

During the last years, women have modified their life profiles with important sociocultural changes. The increase in female participation in the job market has led to a progressive drop in birth rates and postponement of pregnancy. Recent advances in assisted reproduction techniques have contributed to the increase in good results in pregnancies in women of an advanced age. ${ }^{(4)}$

There is no consensus among authors regarding at what maternal age perinatal risk is significantly raised. Although the majority of them uses a cutoff of 40 years as inferior limit, ${ }^{(3,6)}$ others report the age of 35 years. ${ }^{(7,4)}$

Gestation in women aged 35 years or older is associated with maternal complications, such as excessive weight gain, obesity, diabetes mellitus, hypertension, preeclampsia, myoma, besides higher maternal mortality rates. ${ }^{(8)}$ It also increases fetal and newborn complications: chromosomal abnormalities, miscarriages, intrauterine meconium, low birth weight, fetal growth restriction, macrosomia, fetal distress, admission to an intensive therapy unit, and neonatal death. As to gestation and delivery, the most often mentioned disorders are premature labor, antepartum hemorrhage, prolonged labor, multiple gestations, anomalous presentations, dystocia, placenta previa, post-term, oligohydramnios and polyhydramnios, premature rupture of membranes, and cesarean sections. ${ }^{(9,10)}$

The greatest prevalence of clinical and obstetric events in the pregnancy and postpartum period of women aged over 40 years imposes the need for specialized prenatal care, in which prevention is fundamental for the results. ${ }^{(1,11)}$

According to some studies, the past clinical and surgical history, infertility treatment, premature labor, low birthweight, anomalous presentations, and obstetric complications are more frequent in primiparas of an advanced age than in multiparas. This justifies the greater number of cesarean sections, the need for intensive neonatal care, and lower 1-minute Apgar score in such patients..$^{(10,12,13)}$

Maternal mortality increases in advanced-age patients, especially as a result of preeclampsia, placenta previa, postpartum hemorrhage, pulmonary embolism, amniotic fluid embolism and other puerperal complications. ${ }^{(14)}$ In Brazil, data from 2012 of the Information System on Liveborns (Sistema de Informações sobre Nascidos Vivos - Sinasc) showed an increase in the proportion of births in pregnant women over 40 years of age; in that, by $1.75 \%$ in $1996,1.95 \%$ in 2002 , and $2.35 \%$ in 2012. ${ }^{(15)}$

Currently, women who choose to get pregnant after 40 years of age must be aware of the greater maternal and perinatal risks and seek adequate and specialized medical care. ${ }^{(11)}$ According to what is discussed, even more important than age would be her living and health conditions, as well as the quality of prenatal and delivery care. ${ }^{(16)}$

Few national studies cover gestations of women over 35 years of age. Laurenti and Buchalla demonstrated an increase in perinatal mortality in low-weight newborns from mothers at the extreme ends of the reproductive age, as well as those who smoked more than 10 cigarettes a day. ${ }^{(17)}$ Azevedo et al. observed increased prematurity and low birth weight in adolescent and aged pregnant women. ${ }^{(18)}$ Andrade et al. reported a greater number of cesarean sections as well as premature births in gestations of women over 35 years of age. ${ }^{(10)}$ Schupp found a greater frequency of fetal death and of low 1- and 5-minute Apgar scores in pregnant women aged 45 years or older. ${ }^{(11)}$

\section{OBJECTIVE}

To clarify if advanced-age pregnant women were more likely to have adverse perinatal outcomes when compared to those at an ideal reproductive age.

\section{METHODS}

Data were collected from pregnant women who gave birth at the Hospital do Servidor Público Estadual "Francisco Morato Oliveira", in São Paulo (SP), during the period from January $1^{\text {st }}$ to December $31^{\text {st }}, 2008$. The data were stored in electronic spreadsheets (Excel - 
Microsoft Office 2003) and analyzed by means of the Statistical Package for Social Science (SPSS) software, version 15.0.

To prepare this study, twin pregnancies and pregnant women who lacked primary information in their medical records, such as age and gestational age, were excluded.

The groups were divided as per age ranges: age less than 20 years; age equal to or more than 20 years and less than 40 years; and age equal to or more than 40 years. To perform this analysis, absolute and relative frequencies were used for the qualitative variables, and the existence of an association of the characteristics with the age groups was checked using the chisquared $\left(\chi^{2}\right)$ or the likelihood ratio tests. ${ }^{(19)}$ Blood pressure measurements were described per groups as means and standard deviations, and compared among the age groups by using the analysis of variance (ANOVA). ${ }^{(19)}$

Anthropometric variables, gestational history, and characteristics of the deliveries and newborns were evaluated. First, the qualitative characteristics were described by means of relative and absolute frequencies, and the quantitative characteristics by using means and standard deviations. The maternal variables studied were maternal age, arterial blood pressure at admission, parity, gestational age at delivery, and mode of delivery. The neonatal variables studied were 1- and 5- minute Apgar scores, birth weight of the newborn, and birth weight for gestational age. Very advanced age was considered as equal to or more than 45 years.

Additionally, all patients aged less than 40 years were pooled into a single group and compared again to those aged over 40 years. The associations were verified with the $\chi^{2}$ or Fisher's exact tests, and the blood pressure comparisons among the age groups with the Student's $t$ test. ${ }^{(19)}$

Preterm neonates were those born with less than 37 weeks of gestation. To evaluate fetal weight at birth, the intrauterine growth curve according to Alexander et al. ${ }^{(20)}$ was used. The newborn weighing less than the $10^{\text {th }}$ percentile was considered small for gestational age (SGA), and when weighing more than the $90^{\text {th }}$ percentile, large for gestational age (LGA). The tests were performed with a $5 \%$ significance level.

The study was approved by the Research Ethics Committee (CEP, acronym in Portuguese), under number 299.691, CAAE: 00879513.5.0000.5463. Since it was a research project, with data obtained from medical records, there was no need for an Informed Consent Form, which was waived by the Research Ethics Committee.

\section{RESULTS}

During the period between January $1^{\text {st }}, 2008$ and December $31^{\text {st }}$, 2008, there were 920 deliveries at Hospital do Servidor Público Estadual "Francisco Morato Oliveira". Within this period, there were 76 deliveries of patients aged under 20 years and 91 deliveries of patients aged 40 years or more. To form a third group of intermediate ages, data were collected from 92 patients with ages equal to or greater than 20 years and less than 40 years, with a total of 259 patients. The criterion to choose patients of an intermediate age group was the collection of data marked in the database of the Hospital do Servidor Público Estadual "Francisco Morato Oliveira" in an immediate sequence of the patients aged 40 years or more and adding one additional patient. After exclusion of four patients due to twin gestations and lack of data (one of the patients aged 30 years or more and less than 40 years and three patients aged 40 years or more), 255 patients were considered suitable for data analysis.

Table 1 shows that most pregnant women of the sample presented with unruptured membranes $(70 \%)$ and fetal heart rate could be monitored (99\%). Most fetuses were in vertex presentation $(95 \%)$. The most commonly mode of delivery was cesarean section (53\%). Approximately $17 \%$ of the newborns showed alterations (SGA or LGA) according to Alexander classifications. Most mothers were between 20 and 40 years of age (36\%), and the mean maternal age was 30.6 years (standard deviation - SD of 9.9 years). Almost $90 \%$ of the deliveries were full-term; approximately $10 \%$ of the newborns presented with a 1-minute Apgar score under 5 and $2 \%$ presented with a 5-minute Apgar score under 7.

Table 2 shows the cesarean section rates were statistically greater for patients aged 40 years or more and there were fewer forceps or vaginal deliveries $(\mathrm{p}<0.001)$. In the statistical analysis, for the group aged 40 years or older, spinal anesthesia rate was higher $(\mathrm{p}<0.001)$, as well as frequency of male and preterm newborns $(p=0.004)$. There were fewer primigravidas $(\mathrm{p}<0.001)$ in this group.

According to table 3, the results shown with two age groups of pregnant women were the same results observed considering three maternal age groups, but it was also evident that newborns from patients aged 40 years or more presented statistically more 5 -minute 
Table 1. Description of the characteristics of all pregnant women and newborns included in this study

\begin{tabular}{|c|c|}
\hline Variable & $n=255$ \\
\hline \multicolumn{2}{|l|}{ Membranes, n (\%) } \\
\hline Unruptured & $178(69.8)$ \\
\hline Ruptured & $77(30.2)$ \\
\hline \multicolumn{2}{|l|}{ FHR, $n(\%)$} \\
\hline Present & $253(99.2)$ \\
\hline Absent & $2(0.8)$ \\
\hline \multicolumn{2}{|l|}{ Presentation, n (\%) } \\
\hline Vertex & $243(95.3)$ \\
\hline Breech & $12(4.7)$ \\
\hline \multicolumn{2}{|l|}{ Delivery, n (\%) } \\
\hline Vaginal & $103(40.4)$ \\
\hline Cesarean section & $136(53.3)$ \\
\hline Forceps & $16(6.3)$ \\
\hline \multicolumn{2}{|l|}{ Anesthesia, n (\%) } \\
\hline Local & $78(30.6)$ \\
\hline Spinal & $177(69.4)$ \\
\hline \multicolumn{2}{|l|}{ Perineum, n (\%) } \\
\hline Intact & $10(3.9)$ \\
\hline RMLE & $106(41.6)$ \\
\hline Perineal tear & $3(1.2)$ \\
\hline Cesarean section & $136(53.3)$ \\
\hline \multicolumn{2}{|l|}{ Sex, $n(\%)$} \\
\hline Female & $125(49.0)$ \\
\hline Male & $130(51.0)$ \\
\hline \multicolumn{2}{|l|}{ Fetal growth, n (\%) } \\
\hline SGA & $27(10.6)$ \\
\hline$A G A$ & $212(83.1)$ \\
\hline LGA & $16(6.3)$ \\
\hline \multicolumn{2}{|l|}{ Age (years), n (\%) } \\
\hline$\leq 20$ & $76(29.8)$ \\
\hline$>20$ and $<40$ & $91(35.7)$ \\
\hline$\geq 40$ and $<45$ & $85(33.3)$ \\
\hline$\geq 45$ & $3(1.2)$ \\
\hline \multicolumn{2}{|l|}{ Primigravida, $\mathrm{n}(\%)$} \\
\hline No & $122(47.8)$ \\
\hline Yes & $133(52.2)$ \\
\hline \multicolumn{2}{|l|}{ GA - weeks, n (\%) } \\
\hline $24-27$ & $3(1.2)$ \\
\hline $28-32$ & $7(2.7)$ \\
\hline $33-36$ & $17(6.7)$ \\
\hline$\geq 37$ & $228(89.4)$ \\
\hline \multicolumn{2}{|l|}{ 1-minute Apgar score, $\mathrm{n}(\%)^{* *}$} \\
\hline$>5$ & $228(89.8)$ \\
\hline$\leq 5$ & $26(10.2)$ \\
\hline \multicolumn{2}{|l|}{ 5-minute Apgar score, $\mathrm{n}(\%)^{* *}$} \\
\hline$\geq 7$ & $249(98.0)$ \\
\hline$<7$ & $5(2.0)$ \\
\hline \multicolumn{2}{|l|}{ Weight - g, $n(\%)$} \\
\hline$<2,500$ & $25(9.8)$ \\
\hline $2,500-4,000$ & $218(85.5)$ \\
\hline$>4,000$ & $12(4.7)$ \\
\hline Maternal age - years, mean (SD) & $30.6(9.9)$ \\
\hline GA - weeks, mean (SD) & $38.4(2.6)$ \\
\hline Parity - mean (SD) & $1.1(1.5)$ \\
\hline SBP - mean (SD) & $121.1(14.5)$ \\
\hline $\mathrm{DBP}$ - mean $(\mathrm{SD})$ & $77.9(10.7)$ \\
\hline Weight - $g$, mean (SD) & $3.144 .2(632.4)$ \\
\hline
\end{tabular}

Table 2. Description of the variables of interest per mother's age range, considering three age groups and results of the association test

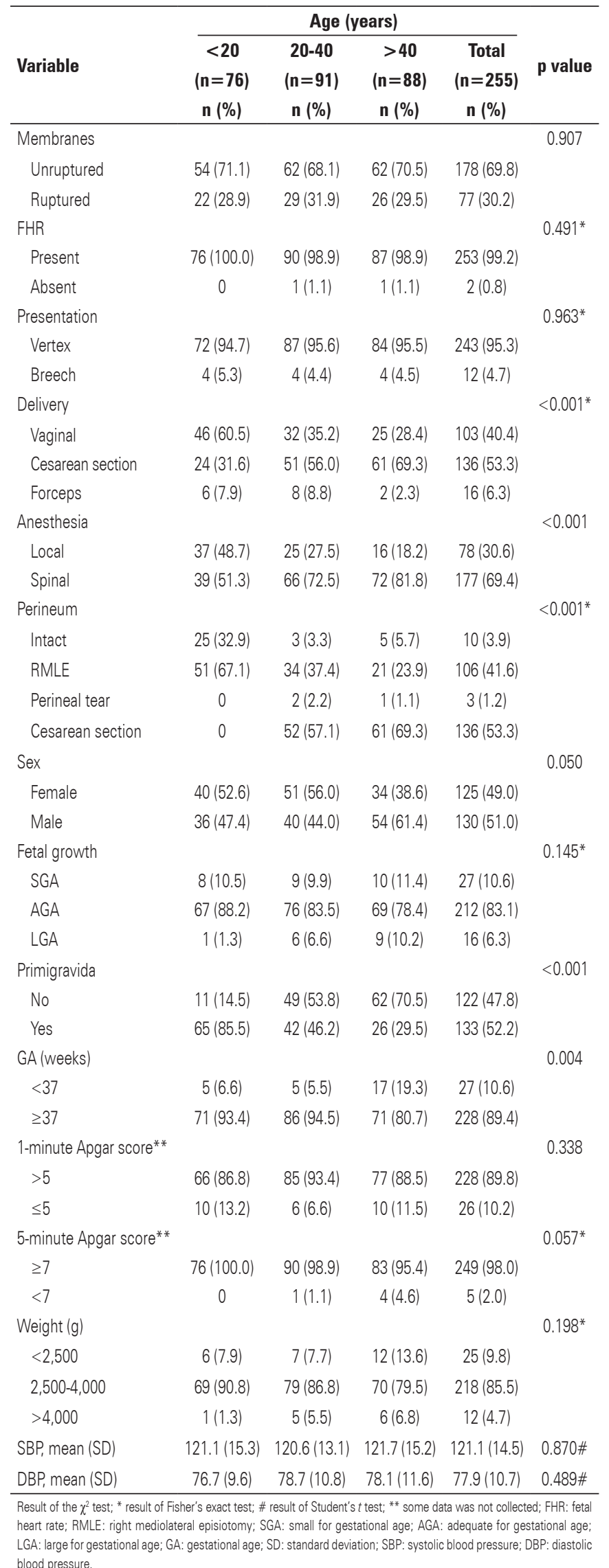


Table 3. Description of the variables of interest per the patient's age group, considering two age groups and the results of association tests

\begin{tabular}{|c|c|c|c|c|}
\hline \multirow[b]{2}{*}{ Variable } & \multicolumn{3}{|c|}{ Age } & \multirow[b]{2}{*}{ p value } \\
\hline & $\begin{array}{c}<40 \\
(n=167) \\
n(\%)\end{array}$ & $\begin{array}{c}\geq 40 \\
(n=88) \\
n(\%)\end{array}$ & $\begin{array}{c}\text { Total } \\
(\mathrm{n}=255) \\
\mathrm{n}(\%)\end{array}$ & \\
\hline Membranes & & & & 0,870 \\
\hline Unruptured & $116(69.5)$ & $62(70.5)$ & $178(69.8)$ & \\
\hline Ruptured & $51(30.5)$ & $26(29.5)$ & $77(30.2)$ & \\
\hline FHR & & & & $>0.999 *$ \\
\hline Present & $166(99.4)$ & $87(98.9)$ & $253(99.2)$ & \\
\hline Absent & $1(0.6)$ & $1(1.1)$ & $2(0.8)$ & \\
\hline Presentation & & & & $>0.999 *$ \\
\hline Vertex & $159(95.2)$ & $84(95.5)$ & $243(95.3)$ & \\
\hline Breech & $8(4.8)$ & $4(4.5)$ & $12(4.7)$ & \\
\hline Delivery & & & & 0.001 \\
\hline Vaginal & $78(46.7)$ & $25(28.4)$ & $103(40.4)$ & \\
\hline Cesarean section & $75(44.9)$ & $61(69.3)$ & $136(53.3)$ & \\
\hline Forceps & $14(8.4)$ & $2(2.3)$ & $16(6.3)$ & \\
\hline Anesthesia & & & & 0.002 \\
\hline Local & $62(37.1)$ & $16(18.2)$ & $78(30.6)$ & \\
\hline Spinal & $105(62.9)$ & $72(81.8)$ & $177(69.4)$ & \\
\hline Perineum & & & & $<0.001 *$ \\
\hline Intact & $28(16.8)$ & $5(5.7)$ & $10(3.9)$ & \\
\hline RMLE & $85(50.9)$ & $21(23.9)$ & $106(41.6)$ & \\
\hline Perineal tear & $2(1.2)$ & $1(1.1)$ & $3(1.2)$ & \\
\hline Cesarean section & $52(31.1)$ & $61(69.3)$ & $136(53.3)$ & \\
\hline Sex & & & & 0.016 \\
\hline Female & $91(54.5)$ & $34(38.6)$ & $125(49.0)$ & \\
\hline Male & $76(45.5)$ & $54(61.4)$ & $130(51.0)$ & \\
\hline Fetal growth & & & & 0.151 \\
\hline SGA & $17(10.2)$ & $10(11.4)$ & $27(10.6)$ & \\
\hline AGA & $143(85.6)$ & $69(78.4)$ & $212(83.1)$ & \\
\hline LGA & $7(4.2)$ & $9(10.2)$ & $16(6.3)$ & \\
\hline Primigravida & & & & $<0.001$ \\
\hline No & $60(35.9)$ & $62(70.5)$ & $122(47.8)$ & \\
\hline Yes & $107(64.1)$ & $26(29.5)$ & $133(52.2)$ & \\
\hline GA (weeks) & & & & 0.001 \\
\hline$<37$ & $10(6.0)$ & $17(19.3)$ & $27(10.6)$ & \\
\hline$\geq 37$ & $157(94.0)$ & $71(80.7)$ & $228(89.4)$ & \\
\hline 1-minute Apgar score ${ }^{* *}$ & & & & 0.633 \\
\hline$>5$ & $151(90.4)$ & $77(88.5)$ & $228(89.8)$ & \\
\hline$\leq 5$ & $16(9.6)$ & $10(11.5)$ & $26(10.2)$ & \\
\hline 5-minute Apgar score ${ }^{* *}$ & & & & $0.048^{*}$ \\
\hline$\geq 7$ & 166 (99.4) & $83(95.4)$ & $249(98.0)$ & \\
\hline$<7$ & $1(0.6)$ & $4(4.6)$ & $5(2.0)$ & \\
\hline Weight (g) & & & & $0.158^{*}$ \\
\hline$<2,500$ & $13(7.8)$ & $12(13.6)$ & $25(9.8)$ & \\
\hline $2,500-4,000$ & $148(88.6)$ & $70(79.5)$ & $218(85.5)$ & \\
\hline$>4,000$ & $6(3.6)$ & $6(6.8)$ & $12(4.7)$ & \\
\hline SBP, mean (SD) & $120.8(14.1)$ & $121.7(15.2)$ & $121.1(14.5)$ & $0.630 \#$ \\
\hline $\mathrm{DBP}$, mean (SD) & $77.8(10.3)$ & $78.1(11.6)$ & $77.9(10.7)$ & $0.841 \#$ \\
\hline
\end{tabular}

Result of the $\chi^{2}$ test. "Result of the likelihood ratio test. " Result of ANOVA. ** ${ }^{*}$ some data was not collected; FHR: fetal heart rate; RMLE: right mediolateral episiotomy; SGA: small for gestational age; AGA: adequate for gestationa age; LGA: large for gestational age; GA: gestational age; SD: standard deviation; SBP: systolic blood pressure; DBP diastolic blood pressure.
Apgar scores $<7$ than the neonates from other mothers $(\mathrm{p}=0.048)$.

\section{DISCUSSION}

To evaluate the group of pregnant women at risk for adverse maternal-fetal outcomes, advanced maternal age was considered when the woman was aged 40 years or more, according to several studies in the literature. ${ }^{(11,21)}$ The term "very advanced maternal age" is currently used more often and includes those aged 45 years or more. ${ }^{(22)}$ In this investigation, the mean age of the women from the group aged 40 years or more was 41.3 years, and of these, $3.2 \%$ presented with a very advanced age. Schupp found a mean age of the pregnant women of 41.7 years, similar to this study, and $9 \%$ of the patients were considered as of a very advanced age, a figure higher superior to what we identified. ${ }^{(11)}$

The frequency of $9.89 \%$ of patients aged 40 years or more found during this period analyzed was similar to that of literature, in which the values are no more than $10 \% .{ }^{(23)}$

Chronic arterial hypertension is the condition most commonly found in advanced age pregnant women. ${ }^{(24)}$ In this study, the values of mean blood pressure were similar among the groups, although some factors, such as prior arterial hypertension, or use of hypotensive medications, were not analyzed.

Patients aged 40 years or more presented with a mean parity superior to the others, a fact verified by means of the number of primigravidas, $29.5 \%$ for the group studied and $64.1 \%$ for the others, with statistically significant difference. This was expected, since women with more advanced age have a greater chance of already having had other pregnancies, a fact that occurs even with a large number of women who postponed their pregnancies to the fourth or fifth decades of life. ${ }^{(25)}$

It was evident that newborns from mothers 40 years of age or more presented with statistically more measurements of 5-minute Apgar score under 7 than the neonates of other mothers $(p=0.048)$, which is confirmed in the study done by Schupp. ${ }^{(11)}$

The mean gestational age of the groups showed a statistically significant difference, which indicates an earlier delivery in late gestations. Astolfi and Zonta reported that the primary factor related to prematurity is maternal age. ${ }^{(26)} \mathrm{A}$ similar study was done by Andrade et al. also at the Hospital do Servidor Público Estadual, between 2000 and 2003, in 16.5\% mothers with premature deliveries for that period. ${ }^{(10)}$ In this study, the incidence of premature births was $19.3 \%$ for women 
of an advanced age, which demonstrates an increase in frequency of this complication, also confirmed in other studies. ${ }^{(27-29)}$ This factor demands that more attention be given to this special group of mothers and that preventive measures be taken to avoid prematurity and all the burden it can convey.

The lowest incidence of post-term in the group of women 40 years of age or more may be due to the greater concern of obstetricians with late gestations, therefore avoiding prolonging of the pregnancies. Edge and Laros showed that the anxiety of the physicians as to the pregnant women in the phase of decreasing fertility, often after the use of assisted reproduction techniques, induced the choice of a cesarean section with no obstetric indication for it..$^{(9)}$

Andrade et al. and Azevedo et al. described a higher incidence of low birth weight in late gestations as well as in SGA neonates, which was not evident in this study in which the mean weight of the newborns was similar among the groups..$^{(10,18)}$

A peculiar and curious fact found was the statistically significant existence of male newborns in the group of late pregnancies.

As to the mode of delivery, there was statistically greater quantity of cesarean sections and fewer forceps or vaginal deliveries, and, consequently, more spinal anesthesia in the pregnant women aged 40 years or more. This was also mentioned in other studies, including a Brazilian study performed in the city of Sarandi (State of Paraná). ${ }^{(9,30)}$ Some maternal conditions associated with possible fetal impairment tend to be more frequent and more severe in women at an advanced age, contributing towards the increased number of cesarean sections, especially due to fetal indication. ${ }^{(10)}$ It is possible that maternal age makes physicians anxious about fetal well-being. ${ }^{(10)}$

The study carried out by Andrade et al. in Brazil showed a $5.5 \%$ incidence of fetal death in mothers over 40 years of age. Our investigation detected $1.1 \%$ of fetal death in this group and $0.6 \%$ in the other mothers, with no significant difference between them, which suggests an improvement in care given to this group of patients. ${ }^{(10)}$

\section{CONCLUSION}

Advanced age as an isolated fact elevates gestational risks, especially in women aged over 40 years. This fact, per se, is an influence on the excessive performance of cesarean sections, making evident the extreme concern with this group.

The significant prematurity found in this study, as well as the lower Apgar score, emphasize the need for prenatal care specific for these patients, acting in prevention and early diagnosis of possible complications.

It is paramount to give priority in care to these women and to organize a reference network for high-risk pregnant woman; hence, prenatal care will be carried out with safety, minimizing maternal complications and improving the perinatal outcomes of this unique group.

\section{REFERENCES}

1. James DK. High risk pregnancy: management options. BMJ. 1995;310(6983): 882-3.

2. Czeizel A. Maternal mortality, fetal death, congenital anomalies and infant mortality at na advanced maternal age. Maturitas.1988;Suppl1:73-81.

3. Spellacy WN, Miller SJ, Winegar A. Pregnancy after 40 years of age. Obstet Gynecol. 1986;68(4):452-4.

4. Prysak M, Lorenz RP, Kisly A. Pregnancy outcome in nulliparous women 35 years and older. Obstet Gynecol. 1995;85(1):65-70.

5. Romero-Maldonado S, Quezada-Salazar CA, López Barrera MD, Arroyo Cabrales LM. [Effect of risk on the child of an older mother (case-control study)] Ginecol Obstet Mex. 2002;70:295-302. Spanish.

6. Brassil MJ, Turner MJ, Egan DM, MacDonald DW. Obstetric outcome in first-time mothers aged 40 years and over. Eur J Obstet Gynecol Reprod Biol. 1987;25(2):115-20

7. Buehler JW, Kaunitz AM, Hogue CJ, Hughes JM, Smith JC, Rochat RW. Maternal mortality in women aged 35 years or older: United States. JAMA 1986;255(1):53-7.

8. Dakov T, Dimitrova V. [Pregnancy and delivery in women above the age of 35] Akush Ginekol (Sofiia). 2014;53(1):13-20. Review. Bulgarian.

9. Edge V, Laros RK Jr. Pregnancy outcome in nulliparous women aged 35 or older. Am J ObstetGynecol 1993;168(6 Pt 1):1881-4; discussion 1884-5.

10. Andrade PC, Linhares JJ, Martinelli S, Antonini M, Lippi UG, Baracat FF. Resultados perinatais em grávidas com mais de 35 anos: estudo controlado. Rev Bras Ginecol Obstet. 2004;26(9):697-701.

11. Schupp TR. Gravidez após os 40 anos de idade: análise dos fatores prognósticos para resultados maternos e perinatais adversos [tese]. São Paulo: Faculdade de Medicina. Universidade de São Paulo; 2006. p. 162.

12. Ecker JL, Chen KT, Cohen AP, Riley LE, Lieberman ES. Increased risk of cesarean delivery with advancing maternal age: indications and associated factors in nulliparous women. Am J Obstet Gynecol. 2001;185(4):883-7.

13. Kozinszky Z, Orvos H, Katona M, Zoboki T, Pál A, Kovács L. Perinatal outcome of induced and spontaneous pregnancies of primiparous women aged 35 or over. Int J Gynaecol Obstet. 2002;76(1):23-6.

14. Jolly M, Sebire N, Harris J, Robinson S, Regan L. The risks associated with pregnancy in women aged 35 years or older. Hum Reprod. 2000;15(11):2433-7.

15. Brasil. Ministério da Saúde. DATASUS. Sitema de informação sobre nascidos vivos (SINASC) [Internet]. Brasília (DF): Ministério da Saúde; 2011 [citado 2015 Abr 1]. Disponível em: http://tabnet.datasus.gov.br/cgi/deftohtm.exe?sinasc/ cnv/nvuf.def

16. Bukulmez 0, Deren 0. Perinatal outcome in adolescent pregnancies: a casecontrol study from a Turkish university hospital. Eur J Obstet Gynecol Reprod Biol. 2000;88(2):207-12.

17. Laurenti R, Buchalla CM. Estudo da morbidade e da mortalidade perinatal em maternidades. II-Mortalidade perinatal segundo peso ao nascer, idade materna, assistência pré-natal e hábito de fumar da mãe. Rev Saude Publica. 1985;19(3):225-32.

18. Azevedo GD, Freitas Júnior RA, Freitas AK, Araújo AC, Soares EM, Maranhão TM. Efeito da idade materna sobre os resultados perinatais. Rev Bras Ginecol Obstet. 2002;24(3):181-5.

19. Kirkwood BR, Sterne JA. Essential medical statistics. 2nd ed. Massachusetts: Blackwell Science; 2003. p. 502. 
20. Alexander GR, Himes JH, Kaufman RB, Mor J, Kogan M. A United States national reference for fetal growth. Obstet Gynecol. 1996;87(2):163-8.

21. Vercellini P, Zuliani G, Rognoni MT, Trespidi L, Oldani S, Cardinale A. Pregnancy at forty and over: a case-control study. Eur J Obstet Gynecol Reprod Biol. 1993;48(3):191-5

22. Callaway LK, Lust K, Mclntyre HD. Pregnancy outcomes in women of very asvanced maternal age. Aust N Z J Obstet Gynecol. 2005;45(1):12-6.

23. Sauer MV, Paulson RJ, Lobo RA. Oocyte donation to women of advanced reproductive age: pregnancy results and obstetrical outcomes in patients 45 years and older. Hum Reprod. 1996;11(11):2540-3.

24. Barton JR, Bergauer NK, Jacques DI, Coleman SK, Stanziano GJ, Sibai BM. Does advanced maternal age affect pregnancy outcome in women with mild hypertension remote from term? Am J Obstet Gynecol. 1997;176(6):1236-40; discussion 1240-3.

25. Adashek JA, Peaceman AM, Lopez-Zeno JA, Minogue JP, Socol ML. Factors contributing to the increased cesarean birth rate in older parturient women. Am J Obstet Gynecol. 1993;169(4):936-40.

26. Astolfi P, Zonta LA. Risks of preterm delivery and association with maternal age, birth order, and fetal gender. Hum Reprod. 1999;14(11):2891-4.

27. Wang LK, Chen WM, Chen CP. Preterm birth trend in Taiwan from 2001 to 2009. J Obstet Gynaecol Res. 2014;40(6):1547-54.

28. Jacquemyn $Y$, Martens $E$, Martens $G$. Pregnancy at late premenopausal age: outcome of pregnancies at 45 years and older in Flanders, Belgium. J Obstet Gynaecol. 2014;34(6):479-81.

29. Phadungkiatwattana P, Rujivejpongsathron J, Tunsatit T, Yanase Y. Analyzing pregnancy outcomes in women of extremely advanced maternal age (> or $=45$ years). J Med Assoc Thai. 2014;97(1):1-6.

30. Sass A, Gravena AA, Pelloso SM, Marcon SS. Resultado perinatais nos extremos da vida reprodutiva e fatores associados ao baixo peso ao nascer Rev Gaucha Enferm. 2011:32(2):352-8. 